Agro-Science Journal of Tropical Agriculture, Food, Environment and Extension Volume 20 Number 3 (July 2021) pp. $65-70$

ISSN 1119-7455

\title{
EXPLORING INTEGRATED PEST MANAGEMENT STRATEGIES IN THE CONTROL OF THE FALL ARMYWORM IN SMALLHOLDER ORGANIC AGRICULTURE FARMS IN AFRICA
}

\author{
Akinyemi A.O. \\ Department of Agronomy, Osun State University, Osogbo, Nigeria \\ Email: adeyemi.akinyemi@uniosun.edu.ng
}

\begin{abstract}
The invasion of the fall armyworm was first reported in Africa in the year 2016. It has since then spread to over 40 countries across Africa, Asia and Australia. Being a polyphagous insect, the potential devastation effects of fall armyworm areenormous, especially amongsmall holder farmers. Currently, most farmers rely on the use of synthetic pesticides for the control of this pest. Organic agriculture however usually has very limited synthetic products approved for the control of pests. Organic production system therefore often depends on ecological processes, biodiversity and cycles adapted to local conditions for the management of pest. This paper reviews the availablemanagement methods applicable to the control of fall armywormthat canbe adopted in an organic agriculture setting. Agroecological methods such as the push-pull technology, crop rotation and other methods including the use of resistant varieties, pheromone traps and biocontrol agents form an important control building block. Integrating these methods in a manner that is acceptable for organic certification will need further research, but it is certainly the way to go in combating the menace of the fall armyworm in organic agricultureand were reviewed in this paper.
\end{abstract}

Key words: agroecological, biological control, pheromone, push-pull, Spodoptera frugiperda

\section{INTRODUCTION}

The fall armyworm, Spodoptera frugiperda (J.E. Smit) (Lepidoptera: Noctuidae) was first reported in Southwestern Nigeria in 2016 (Goergen et al., 2016) and has now spread to over 40 nations in Africa, Asia (Rwomushana et al., 2018) and Australia in 2020 (Anonymous, 2020). It is native to the American continent (Early et al., 2018), where it has been reported to cause significant damage to multiple crops (Knipling, 1980; Montezano et al., 2018). The larval stages of the insect have about 300 plants hosts (Montezano et al., 2018). The ability of the adult stage to fly long distance of about 400 $\mathrm{km}$ per night, in part, accounts for their successful spread (Feldmann et al., 2019). This also probably serves as escape mechanism from density dependent biological regulators that naturally helps to moderate their population (Knipling, 1980). The adult stage can lay 200-300 eggs in masses, and the total eggs produced by a female throughout her lifetime can be up to 2000 eggs which hatch into larvae after a few days (Capinera, 2002). There are up to 6 instar larval stages, and after the $6^{\text {th }}$ instar larva, they change to pupae and then to adults (Capinera, 2002). The developmental period of the fall armyworm fed on fodder maize include: egg incubation period of 2.2 days, the larval stages lasted for about 14 days while the pupal stage lasted for 8.6 days and the total lifecycle from egg to adult is about 25 days (Maruthadurai and Ramesh, 2020).
The damage by the fall armyworm starts from the seedling stage especially on maize plant which is the most preferred. At this stage, the larva feed and browse on young leaves and as the plant grows, the larvae also eat into the growing parts of the plant with obvious and enormous frass deposited on these parts of the plants. The late instar larvae are usually found eating into the plant stem through the top flag leaves and growing point of the plant. The damage associated with fall armyworm is potentially enormous especially among the millions of small-scale farmers in Africa (FAO, 2017; 2018). Up to 8.3-20.6 million tonnes of maize yield losses is possible in Africa if no plant protection methods are employed (Day et al., 2017). Estimated damage in Ethiopia and Kenya are 32 and $47.3 \%$ (Kumela et al., 2019) and maize yield losses due to fall armyworm were estimated at $11.57 \%$ in Zimbabwe (Baudron et al., 2019). In some states in Southwestern Nigeria damage severity could be as high as 50\% (Odeyemi et al., 2020).

According to the International Federation of Organic Agriculture Movement (IFOAM), organic agriculture is defined as a production system that sustains the health of the soils, ecosystems, and people. It relies on ecological processes, biodiversity and cycles adapted to local conditions, rather than the use of inputs with adverse effects. Organic agriculture therefore combines tradition, innovation, and science to benefit the shared 
environment and promote fair relationships and good quality of life for all involved. It is difficult to get reliable data on organic agriculture in Africa, but the certified land area account for $1-3 \%$ of total world organic certified land (UNCTAD-UNEP, 2008). Paradoxically, in terms of number of farms accredited, Africa accounts for about $20 \%$ of all certified farms (Willer and Yussefi, 2007). This reinforces the evidence of abundant smallholder organic farms in Africa (UNCTAD-UNEP, 2008). As expected, organic farmers face the same plant protection and pest problems the conventional farmers face (Letourneau and van Bruggen, 2006). To manage pest problems, organic agriculture relies on preventive methods and the stimulation of biological processes that helps with nutrition, pest management and soil health (IFOAM, 2020). However, for invasive devastating pest such as the fall armyworm, though most conventional farmers rely on the use of synthetic insecticides for its control, in an organic agricultural setting, use of insecticides is largely discouraged because of its negative health and environmental impacts.

A detailed study carried out by Tambo et al. (2020) showed that about $50 \%$ of farmers sampled depended on synthetic pesticides for the management of the fall armyworm. Among other reasons, the use of synthetic pesticide in fall armyworm management is not sustainable or acceptable in organic agriculture because of problems such as development of resistance, killing of beneficial insects including the natural enemies of pest and negative human and animal's health implications of the use of pesticides. Since there are no reports that the invasive fall armyworm that have ravaged over 40 countries in Africa has spared organic farms, the invasion of fall armyworm into farms across Africa will likely be a serious challenge to organic farmers considering the rate at which it spread across Africa. More so, most small-scale farmers in Africa may have limited access to practical research output on effective management methods for the fall armyworm. Awareness of the available methodology in the management of the fall armyworm will therefore be needed to bridge this gap.

The control of fall armyworm in organic agriculture requires an integrated pest management (IPM) approach in which multiple ecological beneficial methods are incorporated into other acceptable methods of control. This integration also encourages increase in population of the natural enemies. According to Bottrell (1979), IPM is "the selection, integration and implementation of pest control based on predicted economic, ecological and sociological consequences". Therefore, some of the principles of IPM can be applied to crop protection in organic agriculture though this must only be with regulated use of pesticide when necessary but must be based on acceptable organic certification standards (Hillocks, 2002).

\section{FALL ARMYWORM CONTROL METHODS} Agroecological Control Methods

Agroecology is an integral part of organic agriculture. The use of ecological protective methods in the management of pest population is therefore most preferred. Some of these methods are often, by default, traditionally used by most small-scale farmers (Adebayo and Oladele, 2014). They are considered beneficial to the environment and it helps to conserve the natural enemies of pests. Agroecological methods in this context include good farm sanitation, minimum tillage practices, crop rotation, manipulation of planting and harvesting date and intercropping (Letourneau and van Bruggen, 2006). These methods are effective in the reduction of the population of the fall armyworm. Apart from its direct benefits in reducing pest population and increasing soil fertility and yield, agroecological methods such as minimum tillage, mulching and intercropping are low-cost options for small holder farmers and are also compatible with other biological control methods (Harrison et al., 2019). Research such as the use of push-pull technology has been shown to be effective in the control of fall armyworm (Midega et al., 2018) based on intercropping and trap cropping agroecological principle. Intercropping maize with other compatible crops will likely increase farmer's income than sole maize in Nigeria (Ibrahim et al., 2019). Weeding and zero tillage also reduce fall armyworm damage (Baudron et al., 2019). Research on the impact of crop rotation on fall armyworm control is scarce but evidence from other pests suggests they may be important in fall armyworm management (Esser et al., 2015).

\section{Host Plant Resistance}

Host plant resistance is an important component of IPM. It is the intentional use of varieties of crops that are resistant to pest's attack alone or in combination with other control managements to reduce the impact of pests on crop yield or quality (Stout, 2014). Screening of available maize germ-plasm, for instance, helps in identifying potential resistance maize varieties. At the moment, there is no known research on varietal screening of crops against the fall armyworm in Nigeria, the second largest producer of maize in Africa (FAOSTAT, 2021). Generally, limited attention has been given to the integration of the conventional derived resistance with other options of pest management (Prasanna et al., 2018). Farmers around the world, especially USA and parts of Asia, have relied on the use of varieties of Bacillus thuringiensis (BT) maize (genetically modified maize) in the management of lepidopteran pests. Development of resistance to BT crops by insect (including the fall armyworm) has threatened the sustainability of this technology (Huang et al., 2014). Moreover, in organic farming, the use of genetically modified organisms such as the BT maize is not acceptable. Therefore, control 
using resistance varieties must rely on the use of conventional breeding methods to be applicable in organic agriculture against the fall armyworm.

Some results have shown variability in the extent of damage by fall armyworm on maize varieties in Mexico, the US and more recently in Kenya (Wiseman and Davis, 1979; Chiriboga et al., 2021). Countries like Nigeria have previously developed varieties of maize that are resistant to pests and diseases before the invasive fall armyworm became a problem (Iken and Amusa, 2004). These varieties can be screened for their resistance against the fall armyworm. Though organic farmers tend to prefer the use of open pollinated varieties to hybrid varieties because of likelihood of more genetic variability (van Bruggen et al., 2016), for pest of economic importance such as the fall armyworm using of hybrid resistance varieties is vital.

\section{Push-Pull Technology}

Push-pull strategy in pest management "involves the behavioral manipulation of insect pests and their natural enemies via the integration of stimuli that act to make the protected resource unattractive or unsuitable to the pests (push) while luring them toward an attractive source (pull) from where the pests are subsequently removed" (Cook et al., 2007). Basically, push-pull pest management method in crops involves intercropping desired crop which may be maize in this context with plant such as desmodium, known to repel insect pest (push), and then surrounding the whole plot with plants or weeds (not the primary desired crop), that are attractive to the pest, which then attract the pest away from the desired crop (pull). This strategy has been successfully used in the management of stem borers and striga weed infesting maize crop and has also been shown to increase soil fertility (Khan et al., 2008; Kumela et al., 2019).

A climate adapted push-pull technology tested in Kenya involving intercrop of maize with drought tolerant green desmodium (Desmodium intortum Mill. Urb.), alongside planting of Brachiaria cV Mulato II (Poaceae) around the maize farm. Desmodium intortum provides semiochemicals that repels armyworm and Brachiaria cv Mulato II attracts the fall armyworm pest away from maize and this technology has been shown to reduce fall armyworm infestation by $82.7 \%$ while also reducing damage by $86.7 \%$ and increasing maize yield up to 2.7 times when compared to monocrop maize (Midega et al., 2018). Similar push-pull climate smart technology has also been shown to reduce fall armyworm, stem borer and striga infestation in Uganda (Hailu et al., 2018). Push-pull technology is generally non-toxic (Cook et al., 2007) and because of its ecological and overall health benefits, it is perfectly appropriate for use in an organic agriculture production system. Awareness on pushpull technology has mostly been limited to the East African countries and may need to be introduced to the South and Western African countries.

\section{Biological Control Methods}

Some of the biological methods used to control fall armyworm are discussed below.

\section{Entomopathogenic organisms and parasitoids}

The use of biological control methods in organic agriculture can be achieved either through conservation of natural enemies or through inundative methods such as introduction of pathogens, parasitoids, and entomopathogenic fungi, once it does not include synthetic carriers (Letourneau and van Bruggen, 2006). As previously mentioned, organic protection methods are primarily based on conservation of available natural enemies within the ecological system but inundative biological control methods are occasionally practiced (Letourneau and van Bruggen, 2006). According to van Bruggen et al. (2016), many potential biocontrol formulations have not been approved for disease control in organic agriculture due to the presence of petrobased synergists or carriers. A few approved ones can be used in situations when plants cannot be protected against pest and disease despite following the acceptable organic production practices. European commission has therefore approved the use of microorganism such as viruses, bacteria and fungi in the management of pest as listed in the Annex II of commission regulation (EC, 2008).

Though more work needs to be done on the use of microorganism in pest management in small holder farms across Africa, available laboratory results from Kenya identified several entomopathogenic organisms that were effective against the fall armyworm. Example, when 20 entomopathogenic fungi were screened for their ovicidal effects against the fall armyworm, Metarhizium anisopliae ICIPE 78, 40 and 20 were found to cause egg mortality of $87 \%, 83 \%$ and $79 \%$, respectively; while ICIPE 41 and ICIPE 7 caused over $95 \%$ mortality of the neonate larvae (Akutse et al., 2019). Also, when 22 fungal isolates were screened for their pathogenicity against adult moth, all the fungi screened were pathogenic to the moth with Beuveri abassiana ICIPE 261 and $M$. anisopliae ICIPE 7 causing $100 \%$ mortality to the moth (fall armyworm) (Akutse et al., 2020).

Predators and parasitoids of the fall armyworm must also be conserved to control fall armyworm multiplication in an organic system. Parasitoid complex of fall armyworm in some parts of Africa including Ghana and Benin Republic, Ethiopia, Kenya and Tanzania show that locally identified egg and larvae parasitoids of fall armyworm are available, most of which belong to the order Hymenoptera (Sisay et al., 2018; Agboyi et al., 2020; Caniço et al., 2020). Identification of available parasitoids is fundamental before they can be applied to the field inundatively or encourage agroecological practices that will favour the development of the natural enemies. 


\section{Use of pheromones and traps}

Pheromones are chemical substances that are produced by an organism and influence the behaviour of another organism in the same species. The common pheromones that have been used in pest management are the sex pheromone, produced by a sex of a species and it attracts the opposite sex and the aggregation pheromone which attracts both sexes of the same species. Pheromones can be used in insect mating disruption and can be applied as a lure in form of "attract and kill" strategy. A sticky trap for instance when baited with pheromone in a dispenser attracts targeted pest to the bait, it gets stuck to the sticky trap and dies. Baited trap can also be used as a lure in an auto dissemination device where the pheromone attracts the insects to a device loaded with entomopathogenic fungi or bacteria. The insects get attracted and infected in the process; the infected insects in turn then infect other insects during feeding or mating activities. Pheromone has shown great potential in pest management in several insects (Furlong et al., 1995; Gut and Brunner, 1998; Witzgall et al., 2010; Sampson and Kirk, 2013; Kabaluk et al., 2015).

In fall armyworm, the females produce sex pheromones including (Z)-9-tetradecenyl acetate, (Z)-7-dodecenyl acetate (Z7-12:Ac), and (Z)-9-dodecenyl acetate (Z9-12:Ac) (Tumlinson et al.,1986; Batista-Pereira et al., 2006; Haenniger et al., 2020). Two potent entomopathogenic fungi, $B$. bassiana ICIPE 261 and M. anisopliae ICIPE 7, have also been found to be compatible with the fall armyworm pheromone (FALLTRACT lure ${ }^{\circledR}$ ). They can be explored in controlling pest population using an auto dissemination approach (Akutse et al., 2020). The European commission approved the use of pheromone as lure in traps or dispensers, as an attractant or sexual behaviour disrupter in the management of major pest in an organic agricultural setting, listed in the Annex II of commission regulation EC 889/2008 (EC, 2008). Therefore, more research into the field application of these pheromones in the control of fall armyworm will be especially useful in organic agriculture.

\section{Use of organic or botanical pesticides}

Unlike synthetic pesticides, plant-based essential oils and plant products are considered less toxic to health and the environment. In cases of major outbreaks of pests that cannot be controlled by other agroecological and environmentally friendly management principles on which organic certification is based, organic product such as azadiractin from neem tree, and other plant oils can be used in managing this pest (EC, 2008). Several plant-based products such as neem and neem oil (Maredia et al.,1992; Roel et al., 2010), essential oil from leaves of Ageratum conyzoides L. (Lima et al., 2010), essential oil of aerial parts of Salvia ballotiflora L. (Cárdenas-Ortega et al., 2015) and several other pesticidal plants (Phambala et al.,
2020) have shown potential in suppressing fall armyworm population. However, most of these researches has been limited to the laboratory and may have to be further tested in a field condition to make them recommendable to organic farmers. Usually, the limitation to the use of plant-based products with insecticidal properties is that their effectiveness is limited; therefore, this control method will have to be combined with other methods for them to be effective.

\section{CONCLUSION}

Considering the level of damage caused by the fall armyworm especially on small scale maize farms across Africa, research targeted at field application of available crop protection strategies is imminent. Limited plant protection products are available for organic farmers, therefore the control of the fall armyworm in organic agriculture will require an integrated management strategy that does not violate organic agriculture certification conditions.

There are common principles of IPM that can be used in organic agriculture because organic agriculture just like IPM is based on integration of environmentally safe management methods. Therefore, some of the principles of IPM reviewed are acceptable when applied to protect organic crops.

The agroecological regular practices in organic agriculture such as crop rotation, intercropping should by default reduce fall armyworm infestation, but this will need further research on ways of optimizing them for this purpose. Push-pull technology is a good example. This is great news especially because push-pull strategy also encourages the presence of the natural enemies and improves soil fertility. This principle has not been tested in all parts of Africa, but such technology, if coupled with the use of varieties that are at least resistant in some degrees and also occasional spray of acceptable biopesticides, could go a long way in helping small scale organic farmers mitigate the problem of fall armyworm. Other methods such as use of pheromone baited traps in form of "attract and kill" and use of "lure and infect" in an auto dissemination device can all be incorporated into the management system as required. Of course, such integrated approach may require further research to confirm synergism, but available evidence suggests that such integrated approach, if professionally researched, will be a sustainable way of managing the invasive fall armyworm in Nigeria.

\section{REFERENCES}

Adebayo S. and Oladele I. (2014). Organic agricultural practices among small holder farmers in Southwestern Nigeria. In: Organic Agriculture towards Sustainability (Chapter 3, pp. 51-66)

Agboyi L., Goergen G., Beseh P., et al. (2020). Parasitoid complex of fall armyworm (Spodoptera frugiperda) in Ghana and Benin. Insects, 11 (2), 68. https://doi.org/10.3390/ insects 11020068 
Akutse K., Khamis F., Ambele F., et al. (2020). Combining insect pathogenic fungi and a pheromone trap for sustainable management of the fall armyworm, Spodoptera frugiperda (Lepidoptera: Noctuidae). J. Invertebr. Pathol., 177, 107477. doi: 10.1016/j.jip.2020.107477

Akutse K., Kimemia J., Ekesi S., Khamis F.M., Ombura O.L. and Subramanian S. (2019). Ovicidal effects of entomopathogenic fungal isolates on the invasive fall armyworm Spodoptera frugiperda (Lepidoptera: Noctuidae). J. Appl. Entomol., 143 (6), 626-634

Annonymous (2020). Fall armyworm in Western Australia. Department of Primary Industry and Regional Development: Agriculture and Food. Accessed $10^{\text {th }}$ Dec. 2020 from: https://www.agric.wa.gov.au/plant-bio security/fall-armyworm-western-australia?nopaging=1

Batista-Pereira L., Stein K., de Paula A., et al. (2006). Isolation, identification, synthesis and field evaluation of the sex pheromone of the Brazilian population of Spodoptera frugiperda. J. Chem. Ecol., 32 (5), 1085-1099

Baudron F., Zaman-Allah M., Chaipa I., Chari N. and Chinwada P. (2019). Understanding the factors influencing fall armyworm (Spodoptera frugiperda JE Smith) damage in African smallholder maize fields and quantifying its impact on yield: A case study in Eastern Zimbabwe. Crop Protect., 120, 141-150

Bottrell D. (1979). Integrated Pest Management. Consortium for International Crop Protection. California, USA. http://ftpmirror.your.org/pub/misc/cd3wd/1004/_ag_415 Integrated Pest Management05 239 jf en $10 \overline{1290}$.pdf

Caniço A., Mexia A. and Santos L. (2020). First report of native parasitoids of fall armyworm Spodoptera frugiperda smith (Lepidoptera: Noctuidae) in Mozambique. Insects, 11 (9), 615. https://doi.org/10.3390/insects11090615

Capinera J.L. (2002). Fall armyworm, Spodoptera frugiperda (JE Smith) (Insecta: Lepidoptera: Noctuidae). EENY-098, University of Florida, Institute of Food \& Agricultural Science IFAS Extension, p. 1-6

Cárdenas-Ortega N., González-Chávez M., FigueroaBrito R., et al. (2015). Composition of the essential oil of Salvia ballotiflora (Lamiaceae) and its insecticidal activity. Molecules, 20 (5), 8048-8059

Chiriboga Morales X., Tamiru A., Sobhy I.S, Bruce T.J.A., Midega C.A.O. and Khan Z. (2021). Evaluation of African maize cultivars for resistance to fall armyworm Spodoptera frugiperda (JE Smith) (Lepidoptera: Noctuidae) larvae. Plants, 10, 392. https://doi.org/10.3390/plants10020392

Cook S.M., Khan Z.R. and Pickett J.A. (2007). The use of push-pull strategies in integrated pest management. Annu. Rev. Entomol., 52, 375-400. DOI: 10.1146/ annurev.ento.52.110405.091407. PMID: 16968206

Day R., Abrahams P., Bateman M., et al. (2017). Fall armyworm: Impacts and implications for Africa. Outlooks Pest Manage., 28 (5), 196-201

Early R., González-Moreno P., Murphy S. and Day R. (2018). Forecasting the global extent of invasion of the cereal pest Spodoptera frugiperda, the fall armyworm. NeoBiota, 40, 25-50. DOI: 10.3897/neobiota.40.28165

EC (2008). European Commission Regulation No. $889 / 2008$ of 5 Sep. 2008 laying down detailed rules for the implementation of council regulation (EC) No $834 / 2007$ on organic production and labeling of organic products with regard to organic production, labelling and control. Official J. Europ. Union L., 250, 1-84
Esser A., Milosavljević I. and Crowder D. (2015). Effects of neonicotinoids and crop rotation for managing wireworms in wheat crops. J. Econ. Entomol., 108 (4), 1786-1794

FAO (2017). Advisory note on FAO action on fall armyworm in Africa. Food and Agricultural Organization, Rome

FAO (2018). Integrated management of the fall armyworm on maize: A Guide for Farmer Field Schools in Africa

FAOSTAT (2021). FAOSTAT Database. Food and Agriculture Organisation (FAO) of the United Nations, Rome, Italy. http://www.fao.org/faostat/en/\#data/QC

Feldmann F., Rieckmann U. and Winter S. (2019). The spread of the fall armyworm Spodoptera frugiperda in Africa-what should be done next? J. Plant Dis. Protect., 126 (2), 97-101

Furlong M.J., Pell J.K., Choo O.P. and Rahman S.A. (1995). Field and laboratory evaluation of a sex pheromone trap for the autodissemination of the fungal entomopathogen Zoophthora radicans (Entomophthorales) by the diamond back moth, Plutella xylostella (Lepidoptera: Yponomeutidae). Bull. Entomol. Res., 85 (3), 331-337

Goergen G., Kumar P., Sankung S., Togola A. and Tamò M. (2016). First report of outbreaks of the fall armyworm Spodoptera frugiperda (JE Smith) (Lepidoptera, Noctuidae): A new alien invasive pest in West and Central Africa. PloS one, 11 (10), e 0165632

Gut L.J. and Brunner J.F. (1998). Pheromone-based management of codling moth (Lepidoptera: Tortricidae) in Washington apple orchards. J. Agric. Entomol., 15 (4), 387-405

Haenniger S., Goergen G., Akinbuluma M., et al. (2020). Sexual communication of Spodoptera frugiperda from West Africa: Adaptation of an invasive species and implications for pest management. Sci. Rep., 10 (1), $1-9$

Hailu G., Niassy S., Zeyaur K., Ochatum N. and Subramanian S. (2018). Maize-legume intercropping and push-pull for management of fall armyworm, stemborers, and striga in Uganda. Agron. J., 110 (6), 2513-2522

Harrison R., Thierfelder C., Baudron F., et al. (2019). Agro-ecological options for fall armyworm (Spodoptera frugiperda JE Smith) management: Providing low-cost, smallholder friendly solutions to an invasive pest. J. Environ. Manag., 243, 318-330

Hillocks R.J. (2002). IPM and organic agriculture for smallholders in Africa. J. Integr. Pest Manage., 7 (1), $17-27$

Huang F., Qureshi J., Meagher Jr R., et al. (2014). Cry1F resistance in fall armyworm Spodoptera frugiperda: Single gene versus pyramided Bt maize. PloS one, 9 (11), e112958

Ibrahim F., Oformata A., Jirgi A. and Adewumi A. (2019). Optimum production plan for maize-based crop farmers in Niger State, Nigeria. Agro-Science, 18 (3), 35-41

IFOAM (2020). Organic agriculture and pesticide. IFOAM Organics International. 52113 Bonn, Germany

Iken J.E. and Amusa N.A. (2004). Maize research and production in Nigeria. Afr. J. Biotechnol., 3 (6), 302-307

Kabaluk J.T., Lafontaine J.P. and Borden J.H. (2015). An attract and kill tactic for click beetles based on Metarhizium brunneum and a new formulation of sex pheromone. J. Pest Sci., 88 (4), 707-716 
Khan Z.R., Midega C.A., Amudavi D.M., Hassanali A. and Pickett J.A. (2008). On-farm evaluation of the 'push-pull' technology for the control of stem borers and striga weed on maize in Western Kenya. Field Crops Res., 106 (3), 224-233

Knipling E.F. (1980). Regional management of the fall armyworm: A realistic approach? Fall Armyworm Symposium. Fla. Entomol., 468-480

Kumela T., Mendesil E., Enchalew B., Kassie M. and Tefera T. (2019). Effect of the push-pull cropping system on maize yield, stem borer infestation and farmers' perception. Agron., 9, 452. https://doi.org/ 10.3390/agronomy9080452

Letourneau D. and van Bruggen A. (2006). Crop Protection in Organic Agriculture (pp. 93-121). CSIRO Publishing, Australia

Lima R.K., Cardoso M.G., Moraes J.C., et al. (2010). Chemical characterization and insecticidal activity of the essential oil leaves of Ageratum conyzoides L. on fall armyworm Spodoptera frugiperda (Smith. 1797) (Lepidoptera: Noctuidae). Biosci. J., 26 (1), 1-5

Maredia K.M., Segura O.L. and Mihm J.A. (1992). Effects of neem, Azadirachta indica on six species of maize insect pests. Int. J. Pest Manag., 38 (2), 190-195

Maruthadurai R. and Ramesh R. (2020). Occurrence, damage pattern and biology of fall armyworm, Spodoptera frugiperda (JE smith) (Lepidoptera: Noctuidae) on fodder crops and green amaranth in Goa, India. Phytoparasitica, 48 (1), 15-23

Midega C.A., Pittchar J.O., Pickett J.A., Hailu G.W. and Khan Z.R. (2018). A climate-adapted push-pull system effectively controls fall armyworm (Spodoptera frugiperda JE Smith.) in maize in East Africa. Crop Protect., 105, 10-15

Montezano D.G., Specht A., Sosa-Gómez D.R., et al. (2018). Host plants of Spodoptera frugiperda (Lepidoptera: Noctuidae) in the America. Afr. Entomol. DOI: 10.4001/003.026.0286

Odeyemi O.O., Lawal B.O., Owolade O.F., et al. (2020). Fall armyworm Spodoptera frugiperda (JE Smith) (Lepidoptera: Noctuidae): Threat to maize production in Nigeria. Nig. Agric. J., 51 (1), 101-108

Phambala K., Tembo Y., Kabambe V., Stevenson P. and Belmain S. (2020). Bioactivity of common pesticidal plants on fall armyworm larvae (Spodoptera frugiperda). Plants, 9 (1), 112. DOI: 10.3390/plants 9010112.PMID:31952351;PMCID:PMC7020173

Prasanna B., Bruce A., Winter S., et al. (2018). Host plant resistance to fall armyworm. In: Prasanna B.M., Huesing J.E., Eddy R. and Peschke V.M. (eds)., Fall Armyworm in Africa: A Guide for Integrated Pest Management (pp. 45-62) (1st ed.). Mexico City, Mexico: The International Maize and Wheat Improvement (CIMMYT)
Roel A., Dourado D., Matias R., Porto K.R.A., Bednaski A.V. and da Costa R.B,. (2010). The effect of sublethal doses of Azadirachta indica (Meliaceae) oil on the midgut of Spodoptera frugiperda (Lepidoptera, Noctuidae). Rev. Bras. Entomol., 54 (3), 505-510

Rwomushana I., Bateman M., Beale T., et al. (2018). Fall Armyworm: Impacts and Implications for Africa. Evidence Note Update, CABI: Wallingford, UK

Sampson C. and Kirk W. (2013). Can mass trapping reduce thrips damage and is it economically viable? Management of the western flower thrips in strawberry. PLoS One, 8 (11), e 80787

Sisay B., Simiyu J., Malusi P., et al. (2018). First report of the fall armyworm Spodoptera frugiperda (Lepidoptera: Noctuidae) natural enemies from Africa. J. Appl. Entomol., 142 (8), 800-804

Stout M.J. (2014). Host-Plant Resistance in Pest Management. In: Integrated Pest Management: Current Concepts and Ecological Perspective (Chapter 1, pp. 1-21). https://doi.org/10.1016/B9780-12-398529-3.00002-6

Tambo J., Day R., Lamontagne-Godwin J., et al. (2020). Tackling fall armyworm (Spodoptera frugiperda) outbreak in Africa: An analysis of farmers' control actions. Int. J. Pest Manag., 66 (4), 298-310

Tumlinson J.H., Mitchell E.R., Teal P.E., Heath R.R. and Mengelkoch L.J. (1986). Sex pheromone of fall armyworm, Spodoptera frugiperda (JE Smith). J. Chem. Ecol., 12 (9), 1909-1926

UNCTAD-UNEP (2008). Organic agriculture and food security in Africa. Capacity Building Taskforce on Trade, Environment and Development. UNEPUNCTAD

van Bruggen A., Gamliel A. and Finckh M. (2016). Plant disease management in organic farming systems. Pest Manag. Sci., 72 (1), 30-44

Willer H. and Yussefi M. (2007). The World of Organic Agriculture, Statistics and Emerging Trends 2007 $\left(9^{\text {th }}\right.$ ed.), International Federation of Organic Agriculture Movements (IFOAM), Bonn, Germany $\&$ Research Institute of Organic Agriculture (FiBL), Frick, Switzerland. http://www.orgprints.org/10506

Wiseman B.R. and Davis F.M. (1979). Plant resistance to the fall armyworm. Fla. Entomol., 123-130

Witzgall P., Kirsch P. and Cork A. (2010). Sex pheromones and their impact on pest management. $J$. Chem. Ecol., 36 (1), 80-100 